\title{
Morphological and molecular evidence indicate Dendronotus primorjensis is a valid species that has priority over D. dudkai (Nudibranchia)
}

\author{
Tatiana A. Korshunova ${ }^{1,3}$, Nadezhda P. Sanamyan², Alexander V. Martynov³ \\ I Koltzov Institute of Developmental Biology RAS, Vavilova Str. 26, 119334 Moscow Russia 2 Kamchatka \\ Branch of Pacific Geographical Institute FEB RAS, Partizanskaya Str. 6, 683000 Petropavlovsk-Kamchatsky \\ Russia 3 Zoological Museum of the Moscow State University, Bolshaya Nikitskaya Str. 6125009 Moscow Russia \\ Corresponding author: AlexanderV.Martynov (martynov@zmmu.msu.ru) \\ Academic editor: N. Yonow | Received 18 August 2016 | Accepted 4 November 2016 | Published 21 November 2016 \\ http://zoobank.org/3378F16E-BD9E-44B3-9799-8BE6583704DB \\ Citation: Korshunova TA, Sanamyan NP, Martynov AV (2016) Morphological and molecular evidence indicate \\ Dendronotus primorjensis is a valid species that has priority over D. dudkai (Nudibranchia). ZooKeys 634: 15-28. doi: \\ 10.3897/zookeys.634.10231
}

\begin{abstract}
Morphological and molecular data of type material of the nudibranch mollusc Dendronotus primorjensis Martynov, Sanamyan, Korshunova, 2015 from the Sea of Japan are summarised and compared with those of D. dudkai Ekimova, Schepetov, Chichvarkhina, Chichvarkhin, 2016. The clear conclusion is that the latter is a junior synonym of Dendronotus primorjensis.
\end{abstract}

\section{Keywords}

Dendronotus, Gastropoda, Mollusca, Nudibranchia, new synonym

\section{Introduction}

Martynov et al. (2015a, b) described the nudibranch Dendronotus primorjensis from the north-west part of the Sea of Japan. The original description of D. primorjensis provided numerous diagnostic features including external characters, detailed scanning electron microscopy images of the radula, as well as remarks about its molecular phylo- 
genetic relationships. The format of that publication precluded publication of lengthy molecular analyses, even though they were performed. Subsequently, Ekimova et al. (2016) described Dendronotus dudkai as new from exactly the same region in which the type material of $D$. primorjensis was collected. Nevertheless Ekimova et al. (2016) considered Dendronotus primorjensis a nomen dubium and presented weak evidence of its invalidity, including allegations that the type material of $D$. primorjensis "are lost if ever existed" (Ekimova et al. 2016: 31). Original type material of Dendronotus primorjensis (holotype and paratype) has been stored in the Zoological Museum of Moscow State University since 2014.

In this publication analysis of combined molecular and morphological data of the holotype and paratype of Dendronotus primorjensis demonstrate that it is a valid species and has taxonomic priority over $D$. dudkai, published one year later.

\section{Material and Methods}

\section{Type material collection}

Type specimens of Dendronotus primorjensis (ZooBank: http://zoobank.org/2001DB85-2005-4E6F-8A21-F15F9068EC7D) have been described previously (Martynov et al. 2015a, b) and were used for both morphological and molecular examinations. The holotype of D. primorjensis (ZMMU Op-419) and the paratype (ZMMU Op-420) were collected in the Sea of Japan, Spokoinaya Bay, at the depth of 2-6.5 m (rocks and algae) on 25 Sept 2014, by T.A. Korshunova and A.V. Martynov using SCUBA diving. Photographs of the living animals were taken by T.A. Korshunova within a day of collection. In addition, staff members of the Diving Center Aquamax (Nakhodka) made additional photographic records immediately upon completion of the collecting dive. These photographs are permanently and publicly available since 30 September of 2014 (Diving Center Aquamax 2014). Afterwards, specimens were fixed in $75 \%$ ethanol for morphological study and in 99\% ethanol for molecular investigations, and registered in the collection of the Zoological Museum of Moscow State University (ZMMU) under the registration numbers Op-419 and Op-420.

\section{Morphological analysis}

All specimens of $D$. primorjensis were examined with a stereomicroscope (MBS-9), a digital camera (Nikon D-90) with a set of extension rings (Kenko), and scanning electron microscope (CamScan Series II) for the original description. The pharynx of the preserved holotype D. primorjensis (ZMMU Op-419) was removed and processed with a weak solution of domestic bleach $(\mathrm{NaOCl})$. The radula of the holotype was examined under SEM at the electron microscopy laboratory of the Biological Faculty of Moscow State University, and these were also published in the original description. 


\section{Molecular analysis}

Small pieces of foot tissue of both specimens of D. primorjensis (ZMMU:Op-419 and ZMMU:Op-420) were used for DNA extraction with Diatom ${ }^{\mathrm{TM}}$ DNA Prep 100 kit (Isogene Lab.) according to the producer's protocols. Extracted DNA was used as a template for the amplification of partial sequences of the mitochondrial genes cytochrome $c$ oxidase subunit I (COI) and 16S, and also the nuclear gene 28S (C1-C2 domain). The primers that were used for amplification are: LCO 1490 (GGTCAACAAATCATAAAGATATTGG, Folmer et al. 1994); HCO 2198 (TAAACTTCAGGGTGACCAAAAAATCA, Folmer et al. 1994); 16S arL (CGCCTGTTTAACAAAAACAT, Palumbi et al. 1991); 16S R (CCGRTYTGAACTCAGCTCACG, Puslednik and Serb 2008); 28 S C1' (ACCCGCTGAATTTAAGCAT, Dayrat et al. 2001); and 28 S C2 (TGAACTCTCTCTTCAAAGTTCTTTTC, Le et al. 1993). Polymerase chain reaction (PCR) amplifications were carried out in a $20-\mu \mathrm{L}$ reaction volume, which included $4 \mu \mathrm{L}$ of 5x Screen Mix (Eurogen Lab), $0.5 \mu \mathrm{L}$ of each primer (10 $\mu \mathrm{M}$ stock), $1 \mu \mathrm{L}$ of genomic DNA, and $14 \mu \mathrm{L}$ of sterile water. The amplification of COI and $28 \mathrm{~S}$ was performed with an initial denaturation for $1 \mathrm{~min}$ at $95^{\circ} \mathrm{C}$, followed by 35 cycles of $15 \mathrm{sec}$ at $95^{\circ} \mathrm{C}$ (denaturation), $15 \mathrm{sec}$ at $45^{\circ} \mathrm{C}$ (annealing temperature), and $30 \mathrm{sec}$ at $72^{\circ} \mathrm{C}$, with a final extension of $7 \mathrm{~min}$ at $72^{\circ} \mathrm{C}$. The $16 \mathrm{~S}$ amplification began with an initial denaturation for $1 \mathrm{~min}$ at $95^{\circ} \mathrm{C}$, followed by 40 cycles of $15 \mathrm{sec}$ at $95^{\circ} \mathrm{C}$ (denaturation), $15 \mathrm{sec}$ at $52^{\circ} \mathrm{C}$ (annealing temperature), and $30 \mathrm{sec}$ at $72^{\circ} \mathrm{C}$, with a final extension of $7 \mathrm{~min}$ at $72^{\circ} \mathrm{C}$. Sequencing for both strands proceeded with the Big Dye v3.1 sequencing kit (Applied Biosystems). Sequencing reactions were analysed using an ABI 3500 Genetic Analyser (Applied Biosystems). Protein-coding sequences were translated into amino acids for confirmation of the alignment. Both sequences of D. primorjensis (ZMMU:Op-419 and ZMMU:Op-420) were deposited in GenBank. Original data and publicly available sequences were aligned with the MUSCLE (Edgar 2004) algorithm. For phylogenetic reconstruction 31 specimens were used. All of the species and their sequences are listed in Table 1.

Two different phylogenetic methods, Bayesian Inference (BI) and Maximum Likelihood (ML) were used to infer evolutionary relationships. Separate analyses were conducted for the following data sets: resulting alignments are $641 \mathrm{bp}$ for COI, $451 \mathrm{bp}$ for 16S, 350 bp for 28S, and 1442 for the concatenated datasets. Evolutionary models for each data set were selected using MrModelTest 2.3 (Nylander et al. 2004) under the Akaike information criterion (Akaike 1974). Bayesian estimation of posterior probability was performed in MrBayes 3.2. Markov chains were sampled at intervals of 500 generations. Analysis was started with random starting trees and $10^{7}$ generations. Maximum likelihood-based phylogeny inference was performed in GARLI 2.0 (Zwickl 2006) with bootstrap in 1000 pseudo-replications. The program TRACER v1.6 was used to examine the convergence results. Additionally, Automatic Barcode Gap Discovery (ABGD) (Puillandre et al. 2012) was used to define species. The ABGD program is available from http://wwwabi.snv.jussieu.fr/public/abgd/abgdweb.html. COI and 16S FASTA alignments were analysed separately (excluding outgroups) using both proposed models: Jukes-Cantor (JC69) and Kimura (K80). The program Mega7 (Kumar et al. 2016) was used to calculate the uncorrected COI p-distances between all the sequences. 
Table I. List of specimens used for phylogenetic analyses.

\begin{tabular}{|c|c|c|c|c|c|}
\hline \multirow{2}{*}{ Species } & \multirow{2}{*}{ Voucher } & \multirow{2}{*}{ Locality } & \multicolumn{3}{|c|}{ GenBank accession nos. } \\
\hline & & & CO1 & $16 S$ & $28 S$ \\
\hline $\begin{array}{l}\text { Dendronotus primorjensis } \\
\text { Martynov et al., } 2015 \\
\text { holotype }\end{array}$ & ZMMU:Op-419 & Russia: Japan Sea & KX672010 & KX672008 & KX672006 \\
\hline $\begin{array}{l}\text { Dendronotus primorjensis } \\
\text { Martynov et al., } 2015 \\
\text { paratype }\end{array}$ & ZMMU:Op-420 & Russia: Japan Sea & KX672011 & KX672009 & KX672007 \\
\hline $\begin{array}{l}\text { Dendronotus dudkai } \\
\text { Ekimova et al., } 2016\end{array}$ & W195 & Russia: Japan Sea & KT031811 & KT031824 & KT031841 \\
\hline $\begin{array}{l}\text { Dendronotus dudkai } \\
\text { Ekimova et al., } 2016\end{array}$ & W196 & Russia: Japan Sea & KT031812 & KT031825 & KT031842 \\
\hline $\begin{array}{l}\text { Dendronotus dudkai } \\
\text { Ekimova et al., } 2016\end{array}$ & W197 & Russia: Japan Sea & KT031813 & KT031826 & KT031843 \\
\hline $\begin{array}{l}\text { Dendronotus dudkai } \\
\text { Ekimova et al., } 2016\end{array}$ & W198 & Russia: Japan Sea & KT031814 & KT031827 & KT031844 \\
\hline $\begin{array}{l}\text { Dendronotus dudkai } \\
\text { Ekimova et al., } 2016\end{array}$ & W199 & Russia: Japan Sea & KT031815 & KT031828 & KT031845 \\
\hline $\begin{array}{l}\text { Dendronotus dudkai } \\
\text { Ekimova et al., } 2016\end{array}$ & W201 & Russia: Japan Sea & KT031816 & KT031829 & KT031837 \\
\hline $\begin{array}{l}\text { Dendronotus dudkai } \\
\text { Ekimova et al., } 2016\end{array}$ & W202_1 & Russia: Japan Sea & KT031817 & KT031830 & KT031838 \\
\hline $\begin{array}{l}\text { Dendronotus dudkai } \\
\text { Ekimova et al., } 2016\end{array}$ & W202_2 & Russia: Japan Sea & KT031818 & KT031831 & KT031840 \\
\hline $\begin{array}{l}\text { Dendronotus dudkai } \\
\text { Ekimova et al., } 2016\end{array}$ & W203 & Russia: Japan Sea & KT031819 & KT031832 & KT031839 \\
\hline $\begin{array}{l}\text { Dendronotus dalli } \\
\text { Bergh, } 1879\end{array}$ & ZMMU:Op-295 & $\begin{array}{c}\text { Russia: } \\
\text { Kamchatka }\end{array}$ & KM397001 & KM397083 & KM397042 \\
\hline $\begin{array}{l}\text { Dendronotus dalli } \\
\text { Bergh, } 1879\end{array}$ & ZMMU:Op-330 & $\begin{array}{c}\text { Russia: } \\
\text { Kamchatka }\end{array}$ & KM396999 & KM397081 & KM397040 \\
\hline $\begin{array}{l}\text { Dendronotus frondosus } \\
\text { (Ascanius, 1774) }\end{array}$ & ZMMU:Op-380 & Norway & KM396976 & KM397056 & KM397017 \\
\hline $\begin{array}{l}\text { Dendronotus frondosus } \\
\text { (Ascanius, 1774) }\end{array}$ & ZMMU:Op-324 & $\begin{array}{c}\text { Russia: } \\
\text { Barents Sea }\end{array}$ & KM396980 & KM397062 & KM397021 \\
\hline $\begin{array}{l}\text { Dendronotus kalikal } \\
\text { Ekimova et al., } 2015\end{array}$ & ZMMU:Op-284.3 & $\begin{array}{c}\text { Russia: } \\
\text { Kamchatka }\end{array}$ & KM396988 & KM397070 & KM397029 \\
\hline $\begin{array}{l}\text { Dendronotus kalikal } \\
\text { Ekimova et al., } 2015\end{array}$ & ZMMU:Op-349.1 & $\begin{array}{c}\text { Russia: } \\
\text { Kamchatka }\end{array}$ & KM396986 & KM397068 & KM397027 \\
\hline $\begin{array}{l}\text { Dendronotus kamchaticus } \\
\text { Ekimova et al., } 2015\end{array}$ & ZMMU:Op-246.2 & $\begin{array}{c}\text { Russia: } \\
\text { Kamchatka }\end{array}$ & KM396989 & KM397072 & KM397030 \\
\hline $\begin{array}{l}\text { Dendronotus kamchaticus } \\
\text { Ekimova et al., } 2015\end{array}$ & ZMMU:Op-247.1 & $\begin{array}{c}\text { Russia: } \\
\text { Kamchatka }\end{array}$ & KM396991 & KM397073 & KM397032 \\
\hline $\begin{array}{l}\text { Dendronotus lacteus } \\
\text { (W. Thompson, 1840) }\end{array}$ & ZMMU:Op-288 & $\begin{array}{c}\text { Russia: } \\
\text { Barents Sea }\end{array}$ & KM396975 & KM397059 & KM397016 \\
\hline $\begin{array}{l}\text { Dendronotus lacteus } \\
\text { (W. Thompson, 1840) }\end{array}$ & ZMMU:Op-335 & $\begin{array}{c}\text { Russia: } \\
\text { Barents Sea }\end{array}$ & KM396973 & KM397057 & KM397014 \\
\hline $\begin{array}{l}\text { Dendronotus niveus } \\
\text { Ekimova et al., } 2015\end{array}$ & ZMMU:Op-269 & $\begin{array}{l}\text { Russia: } \\
\text { White Sea }\end{array}$ & KM396996 & KM397078 & KM397037 \\
\hline
\end{tabular}




\begin{tabular}{|c|c|c|c|c|c|}
\hline \multirow{2}{*}{ Species } & \multirow{2}{*}{ Voucher } & \multirow{2}{*}{ Locality } & \multicolumn{3}{|c|}{ GenBank accession nos. } \\
\hline & & & $\mathrm{CO1}$ & $16 S$ & $28 S$ \\
\hline $\begin{array}{l}\text { Dendronotus niveus } \\
\text { Ekimova et al., } 2015\end{array}$ & ZMMU:Op-279 & $\begin{array}{c}\text { Russia: } \\
\text { Barents Sea }\end{array}$ & KM396995 & KM397077 & КМ397036 \\
\hline $\begin{array}{l}\text { Dendronotus patricki } \\
\text { Stout et al., } 2011\end{array}$ & SIO-BIC M12133 & USA: California & HQ225828 & HQ225829 & - \\
\hline $\begin{array}{l}\text { Dendronotus regius } \\
\text { Pola \& Stout, } 2008\end{array}$ & CASIZ179492 & Philippines & HM162708 & HM162629 & - \\
\hline $\begin{array}{l}\text { Dendronotus robustus } \\
\text { Verrill, } 1870\end{array}$ & ZMMU:Op-343 & $\begin{array}{c}\text { Russia: } \\
\text { Barents Sea }\end{array}$ & KM397002 & KM397084 & КМ397043 \\
\hline $\begin{array}{l}\text { Dendronotus robustus } \\
\text { Verrill, } 1870\end{array}$ & ZMMU:Op-344 & $\begin{array}{c}\text { Russia: } \\
\text { Barents Sea }\end{array}$ & KM397003 & KM397085 & KM397044 \\
\hline $\begin{array}{l}\text { Doto coronata } \\
(\mathrm{Gmelin}, 1791)\end{array}$ & CASIZ176278 & South Africa & HM162734 & HM162657 & - \\
\hline $\begin{array}{l}\text { Doto koenneckeri } \\
\text { Lemche, } 1976\end{array}$ & CASIZ178247 & Portugal & HM162735 & HM162658 & - \\
\hline $\begin{array}{l}\text { Marionia arborescens } \\
\text { Bergh, } 1890\end{array}$ & CAS:177735 & Philippines & KP226855 & KP226859 & - \\
\hline $\begin{array}{l}\text { Tritonia challengeriana } \\
\text { Bergh, } 1884\end{array}$ & CASIZ171177 & $\begin{array}{c}\text { Atlantic Ocean: } \\
\text { Bouvet Island }\end{array}$ & HM162718 & HM162643 & - \\
\hline
\end{tabular}

\section{Results}

\section{Morphological characters of Dendronotus primorjensis}

The holotype of D. primorjensis (ZMMU Op-419, Fig. 1A, B) and paratype (ZMMU Op-420, Fig. 1C, D) possess the following morphological features: body elongate, high, laterally compressed. Living length $21-35 \mathrm{~mm}$. Oral veil narrow with 7-8 large branched appendages. Branched lateral papilla at middle of rhinophoral sheaths. Five appendages of rhinophoral stalks, 8-11 rhinophoral lamellae. 5-6 pairs of highly branched dorsolateral appendages, decreasing in size and branching towards tail. Digestive gland branches penetrate most dorsolateral appendages as well as rhinophoral sheaths. Dorsolateral appendages with long primary stalk, secondary branches, and elongate tertiary branches (Fig. 1A-D). Dorsal surface tuberculate. Foot narrow, rounded in front, narrowed towards tail. Reproductive opening placed laterally on right side at level of first pair of dorsolateral appendages. Anal opening on right side between first and second pairs of dorsolateral appendages. Colour non-uniformly reddish brown with few opaque white stripes between dorsolateral processes (holotype, Fig. 1A), more uniformly olive almost without white pigment (paratype, Fig. 1C), or almost lacking general pigmentation. Dorsum, dorsolateral appendages, and upper sides of foot with small scattered whitish and yellowish dots. 7-12 lip papillae. Dorsal processes of the jaws inclined posteriorly at approximately $47^{\circ}$ to the longitudinal axis of the jaw body and 0.48 of its length; denticles present. Radular formula $37 \times 8-9.1 .9-8$ (holotype) (Fig. 1E, F). Central tooth strong, distinctly denticulate in both anterior and posterior parts of radula, with up to 14 denticles (Fig. 1E, F) 

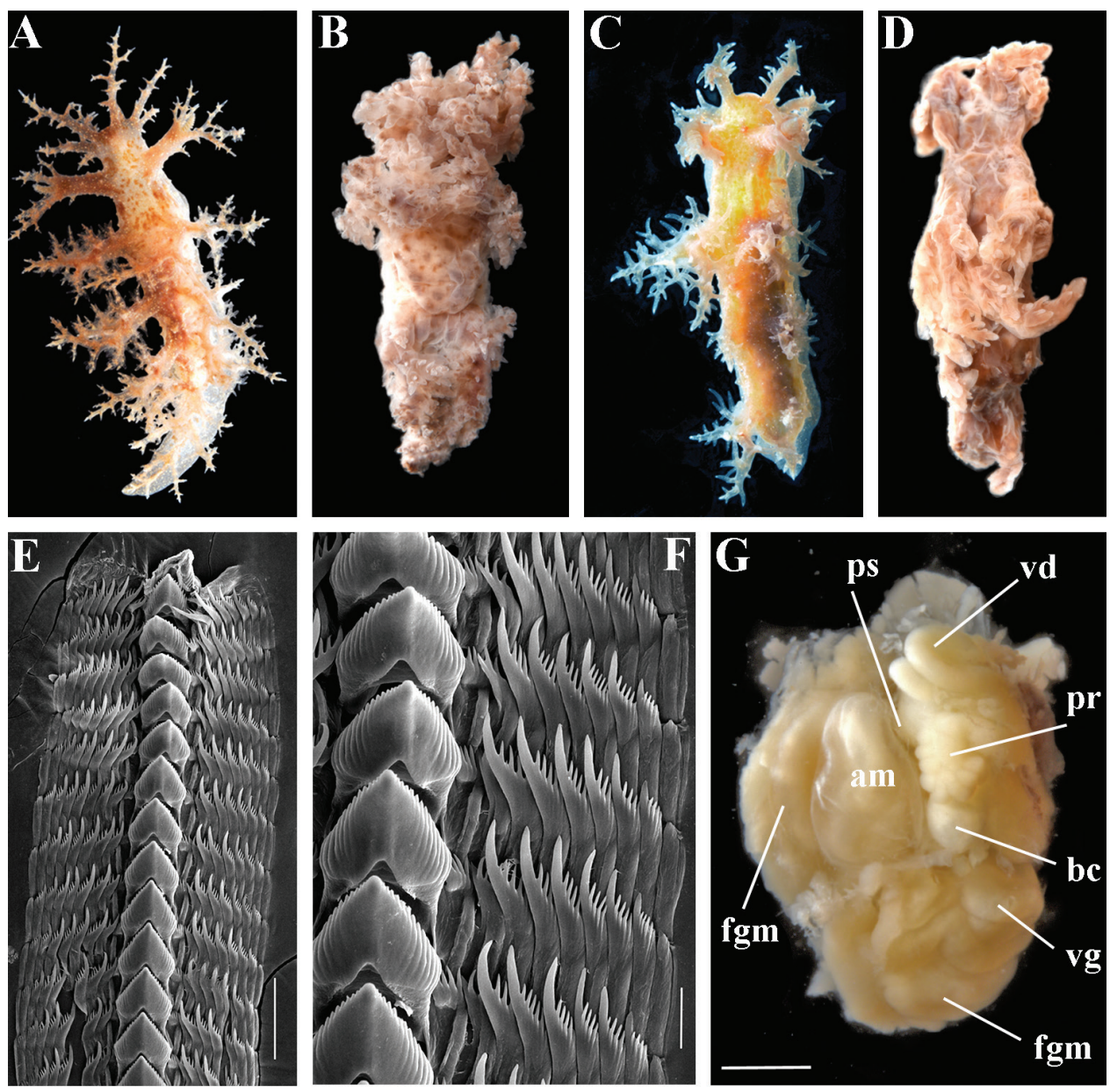

Figure I. Dendronotus primorjensis, type material from Zoological Museum MSU: A holotype ZMMU Op-419, live, $35 \mathrm{~mm}$ in length, dorsal view B fixed holotype ZMMU Op-419 C paratype ZMMU Op420, live, $21 \mathrm{~mm}$ in length D fixed paratype ZMMU Op-420 E radula of the holotype ZMMU Op-419, posterior part, SEM; $\mathbf{F}$ same, details $\mathbf{G}$ reproductive system of the holotype ZMMU Op-419. Abbreviations: am ampulla; bc bursa; fgm female gland mass; $\mathbf{p r}$ prostate; $\mathbf{p s}$ penial sheath; vd vas deferens; $\mathbf{v g}$ vagina. Scale bars $\mathbf{E}=100 \mu \mathrm{m} \mathbf{F}=30 \mu \mathrm{m} \mathbf{G}=1 \mathrm{~mm}$. Photos and SEM images by T.A. Korshunova and A.V. Martynov (Figures A, E, and F were published as part of the original description by Martynov et al. 2015a).

bearing deep furrows. Lateral teeth narrow, with relatively long curved cusp, bearing 3-6 distinct denticles (Fig. 1F). Outermost lateral teeth almost devoid of denticles. Reproductive system triaulic (Fig. 1G), ampulla twice folded. Prostate in holotype rounded, consists of no less than 19 alveolar glands. Distal part of vas deferens relatively short, entangled, and expanded to oval penial sheath and relatively long and curved conical penis. Vagina moderate in length. Bursa copulatrix large, rounded, elongated, seminal receptaculum placed distally (nomenclature of the seminal reservoirs according to Stout et al. 2011). 


\section{Morphological characters of Dendronotus dudkai}

These characters are taken directly from Ekimova et al. (2016: 35, 37, shortened):

"Body elongate, laterally compressed [the range of the lengths of specimens was not recorded in the description of D. dudkai by Ekimova et al. (2016), and only from the figure legends is it possible to estimate that length can be up to $28 \mathrm{~mm}$ ]. Oral veil with 6-12 large, secondary branched cerata. 5-10 short lip papillae. Rhinophoral sheaths with long stalk and 4-5 crown secondary branched appendages. Lateral papillae moderate in size with small secondary branches. Rhinophores with 8-10 lamellae. 6-8 pairs of highly branched dorsolateral processes, size and degree of branching decrease towards the tail. Secondary branches long and rounded, tertiary branches short and sometimes pointed. General colour pattern varies from beige to dark-brown. Background colour translucent-white or light yellow. A lot of spots, stripes and dots on dorsal side of the body, cerata, rhinophoral sheath processes and upper parts of foot. Their colour varies from yellow to dark-brown. Some specimens covered with dots of golden or white opaque pigment. This pigment locates also in low body papillae and small tubercles. All specimens possess well-visible white stripes between pairs of cerata. Dorsal processes of jaws about 2.5 times shorter than jaw body. Inclined posteriorly at about $45^{\circ}$. Masticatory process about one-third as long as jaw body, slightly curved at base and become transparent and subulate posteriorly. Masticatory border with a single raw of denticles. Radula formula up to $32 \times 7-8.1 .7-8$. Rachidian tooth bears 12-18 sharp denticles with thin furrows on both sides of the reduced cusp. Lateral teeth slightly curved, bear 4-8 well-defined denticles. Reproductive system triaulic. Ampulla wide and sinuous. Prostate concentric ring-shaped, consists of 12-14 oval alveolar glands. Distal part of vas deference winding expand into wide, muscular portion. Penis slightly curved. Oviduct connects through insemination duct into female gland complex. Vagina long, convoluted, rounded seminal receptaculum, small bursa copulatrix" [according to the updated nomenclature by Stout et al. 2011, receptaculum = bursa and vice versa].

\section{Phylogenetic analysis}

Brief molecular results, including the genetic distances between Dendronotus primorjensis and closely related species were provided in two previous studies (Martynov et al. 2015a, b). In this study an extended molecular analysis is provided for a detailed comparison of the molecular data between $D$. primorjensis and $D$. dudkai.

Phylogenetic analyses were separately performed for COI, 16S, and $28 \mathrm{~S}$ genes, and three concatenated nucleotide datasets from the holotype and paratype of $D$. primorjensis, available Dendronotus specimens from GenBank, and an outgroup consisting of four species of Doto, Tritonia, and Marionia (Table 1). Trees of both Bayesian Inference (BI) and Maximum Likelihood (ML) were used to infer phylogenetic trees. All single-gene trees as well as concatenated trees revealed very low divergence between $D$. primorjensis 


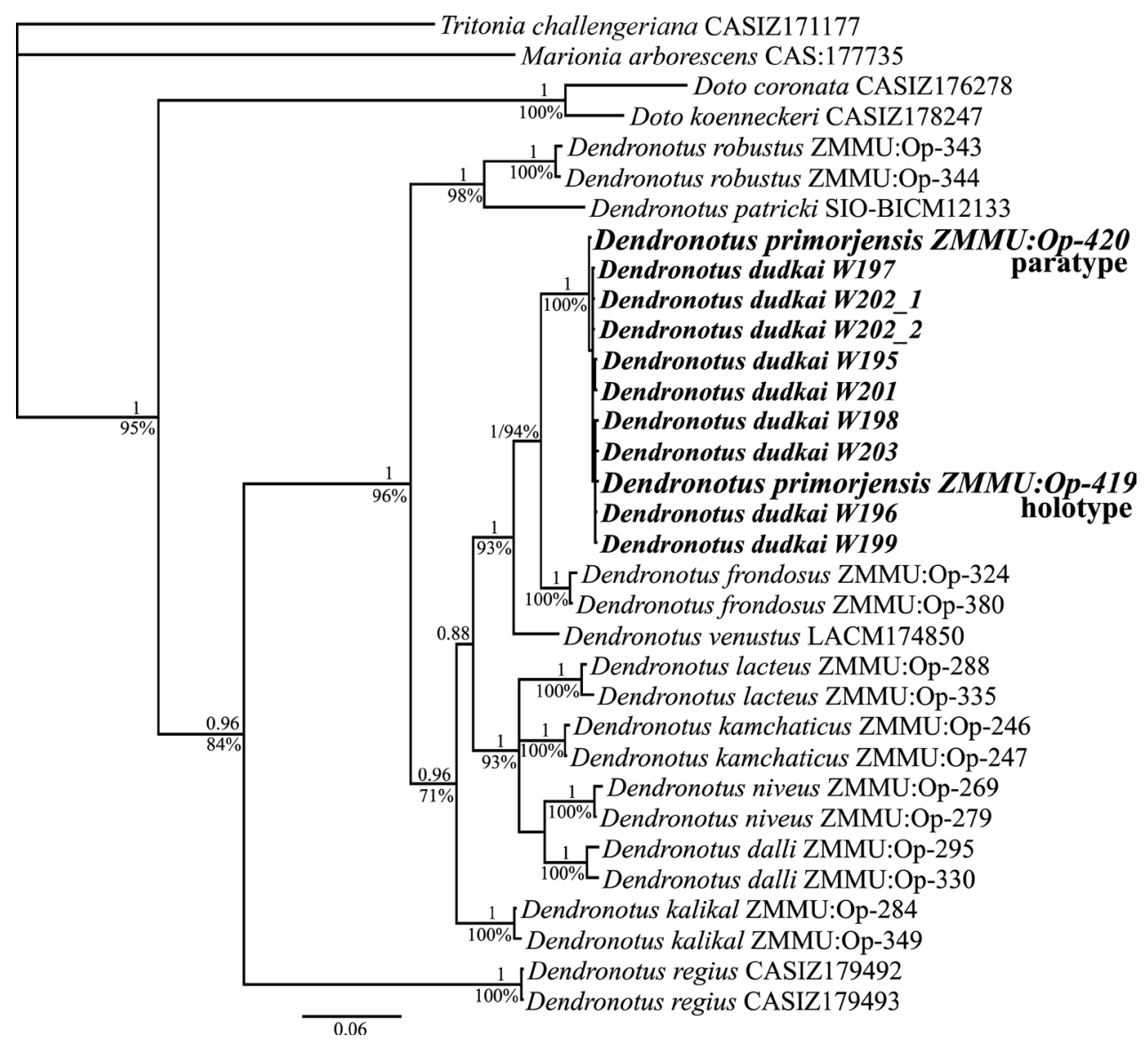

Figure 2. Phylogenetic tree based on combined molecular data (COI $+16 S+28 S)$ represented by Bayesian Inference. Numbers above branches represent posterior probabilities from BI. Numbers below branches indicate bootstrap values for Maximum Likelihood.

and $D$. dudkai specimens. A phylogenetic tree based on combined molecular data is represented in Figure 2. The combined data set including the three loci was presented in a sequence alignment of 1442 codon positions. The General Time Reversal model with invariant sites and gamma distribution $(\mathrm{GTR}+\mathrm{I}+\mathrm{G})$ was selected as the best model for three nucleotide datasets. The topologies of phylogenetic trees inferred from two methods (ML and $\mathrm{BI}$ ) and three datasets were identical. Dendronotus primorjensis and D. dudkai specimens are clustered in a single clade with maximum support $(\mathrm{PP}=1, \mathrm{BS}=100 \%)$.

The ABGD analysis of the COI data set run with two different models revealed eleven potential species each:

D. regius (CASIZ179492, CASIZ179493);

D. lacteus (ZMMU:Op-288, ZMMU:Op-335);

D. kamchaticus (ZMMU:Op-246, ZMMU:Op-247); 
D. niveus (ZMMU:Op-269, ZMMU:Op-279);

D. dalli (ZMMU:Op-295, ZMMU:Op-330);

D. kalikal (ZMMU:Op284, ZMMU:Op349);

D. venustus (LACM174850);

D. primorjensis (ZMMU:Op-419, ZMMU:Op-420) together with D. dudkai (W195, W196, W197, W198, W199, W201, W202_1, W202_2, W203);

D. frondosus (ZMMU:Op-380, ZMMU:Op-324);

D. patricki (SIO-BICM12133);

D. robustus (ZMMU:Op-343; ZMMU:Op-344).

The prior maximal distance ranged between 0.001 and 0.059 .

The ABGD analysis of the $16 \mathrm{~S}$ data set run with two different models revealed ten potential species each:

D. regius (CASIZ179493, CASIZ179492);

D. robustus (ZMMU: Op344, ZMMU:Op343);

D. patricki (SIO-BIC M12133);

D. kalikal (ZMMU:Op349, ZMMU:Op349);

D. venustus (LACM:174852.1);

D. frondosus (ZMMU:Op324, ZMMU:Op380) together with $D$. primorjensis (ZMMU:Op-419, ZMMU:Op-420) together with D. dudkai (W195, W196, W197, W198, W199, W201, W202_1, W202_2, W203);

D. niveus (ZMMU:Op269, ZMMU:Op279);

D. lacteus (ZMMU:Op288, ZMMU:Op335);

D. kamchaticus (ZMMU:Op247, ZMMU:Op246);

D. dalli (ZMMU:Op295, ZMMU:Op330).

The prior maximal distance ranged between 0.001 and 0.021 .

Results for genetic distances between Dendronotus primorjensis, $D$. frondosus, $D$. venustus, D. kalikal, and D. kamchaticus have been described previously (Martynov et al. 2015b). Uncorrected COI p-distances between the holotype and paratype of $D$. primorjensis and other species of the genus Dendronotus are listed in Table 2. The COI p-distances of $D$. primorjensis - D. dudkai specimens range from 0 to $0.31 \%$, indicating a strong overlap in the molecular dataset. Thus, the results unmistakeably indicate that $D$. primorjensis and $D$. dudkai belong to the same species, and $D$. dudkai is here regarded as a junior synonym.

\section{Discussion}

According to the morphological and molecular data presented above there are no species-level differences between $D$. primorjensis (Figs 1 and 2; Table 2) and D. dudkai (Ekimova et al. 2016: 33-37). Molecular analysis robustly places the holotype of $D$. 
Table 2. Uncorrected COI p-distances (\%) between holotype and paratype of Dendronotus primorjensis and other species of the genus Dendronotus.

\begin{tabular}{|c|c|c|}
\hline Species & $\begin{array}{l}\text { Dendronotus primorjensis } \\
\text { ZMMU:Op-419 holotype }\end{array}$ & $\begin{array}{l}\text { Dendronotus primorjensis } \\
\text { ZMMU:Op-420 paratype }\end{array}$ \\
\hline Dendronotus primorjensis paratype & 0.16 & - \\
\hline Dendronotus dudkai KT031811 & 0.16 & 0.31 \\
\hline Dendronotus dudkai KT031814 & 0.16 & 0.31 \\
\hline Dendronotus dudkai KT031816 & 0.16 & 0.31 \\
\hline Dendronotus dudkai KT031819 & 0 & 0.16 \\
\hline Dendronotus dudkai KT031812 & 0 & 0.16 \\
\hline Dendronotus dudkai KT031813 & 0 & 0.16 \\
\hline Dendronotus dudkai KT031815 & 0 & 0.16 \\
\hline Dendronotus dudkai KT031817 & 0 & 0.16 \\
\hline Dendronotus dudkai KT031818 & 0 & 0.16 \\
\hline Dendronotus frondosus KM396976 & 6.71 & 6.55 \\
\hline Dendronotus venustus HM162709 & 8.11 & 7.96 \\
\hline Dendronotus kalikal KM396986 & 11.2 & 11.4 \\
\hline Dendronotus kamchaticus KM396989 & 11.86 & 11.7 \\
\hline Dendronotus albopunctatus GQ292064 & 12.01 & 11.86 \\
\hline Dendronotus niveus KM396996 & 12.32 & 12.17 \\
\hline Dendronotus dalli KM397001 & 13.88 & 13.73 \\
\hline Dendronotus lacteus KM396975 & 14.51 & 14.35 \\
\hline Dendronotus patricki HQ225828 & 14.7 & 14.5 \\
\hline Dendronotus robustus KM397002 & 14.8 & 14.7 \\
\hline Dendronotus regius HM162708 & 16.8 & 16.7 \\
\hline
\end{tabular}

primorjensis inside the clade of $D$. dudkai (Fig. 2). Both the external and internal morphologies, as well as radular and reproductive features, do not demonstrate any significant differences between the two. Other differences between the original descriptions of $D$. primorjensis and $D$. dudkai are discussed below.

Since $D$. frondosus is a closely related species to $D$. primorjensis (=D. dudkai syn. n.) (Fig. 2) and, according to Ekimova et al. (2016), co-occurs with D. primorjensis in the Sea of Japan, it is important to discuss distinguishing morphological characters between these two species as well as their biogeographical patterns. In the first description of $D$. primorjensis "an absence of the large amount of the white pigment" was described as a potential distinguishing external character from $D$. frondosus and the eastern Pacific related species D. venustus (Martynov et al. 2015a: 60). This statement was challenged by Ekimova et al. (2016: 31,35) who claim that "all specimens possess well-visible white stripes between pairs of cerata." However, surprisingly, on the figures of D. dudkai (Ekimova et al. 2016: fig. 9A, C) no white pigment is visible, thus in full agreement with the data on both the holotype and paratype of $D$. primorjensis (Martynov et al. 2015: 60, Fig. 5A-G and present study, Fig. 1A, C). The colour pat- 
terns of $D$. frondosus and D. venustus vary considerably (Robilliard 1970; pers. obs.) and $D$. primorjensis is potentially expected to have similar variations. However, to date no specimens of $D$. primorjensis with really large amounts of white pigment between the dorsolateral appendages have been reported (as previously documented for D. frondosus and $D$. venustus).

Ekimova et al. (2016: 37) claim that " $D$. frondosus is differentiated from $D$. dudkai by the absence of denticles on the masticatory process of jaws" but this is in error: in Robilliard's review on the genus Dendronotus, the presence of denticles has been indicated for $D$. frondosus sensu lato ("A small number of relatively large, black denticles adorns the masticatory margin", Robilliard 1970: 443). Furthermore, since Robilliard's study refers to a mixture of $D$. frondosus s. str. and D. venustus MacFarland, 1966 (but anyway not $D$. primorjensis) we have studied a topotype of $D$. frondosus s. str. from the North Atlantic (Norway) to clarify the situation. Species identity was confirmed using both morphological and molecular data: the topotype of D. frondosus s. str. demonstrated several small but distinct denticles on the jaws. In the original description of $D$. venustus, numerous denticles (between 27 and 40) on the masticatory processes were also described (MacFarland 1966: 277). Thus, the presence of denticles on the masticatory processes of the jaws cannot serve as a diagnostic character for $D$. primorjensis (= D. dudkai syn. n.) despite claims by Ekimova et al. (2016).

Instead, it is suggested here that the number of denticles on the central teeth is a better diagnostic, and is higher in $D$. primorjensis (commonly more than 12 , in holotype 14 , reported range 12-18) than in D. frondosus (commonly up to 12 , rarely up to 14 denticles in the topotype specimens from North Atlantic, pers. obs., reported range 8-12). The original description of the $D$. primorjensis is accompanied by two detailed SEM images of the radula (see Martynov et al. 2015a: fig. 5). On these images up to 14 denticles of the central radular tooth can be recognized, whereas according to Ekimova et al. (2016), the central tooth of $D$. frondosus from the Sea of Japan bears a maximum of 12 denticles. Therefore, a larger number of denticles on the central teeth of $D$. primorjensis distinguishes it from the Japan Sea's D. frondosus, but was not discussed by Ekimova et al (2016). No other species of Dendronotus with a similar radula have been so far reported from the Sea of Japan. The discussion of the origin of D. frondosus in the Sea of Japan in the Ekimova et al. (2016: 38-39) mainly concentrates on the idea that $D$. frondosus could be a natural amphiboreal species. However, the fact that the only Japan Sea D. frondosus specimens recorded in Ekimova et al. (2016) were found exclusively in the vicinity of the Institute of Marine Biology FEB RAS (Vladivostok) indicates a high probability of anthropogenic introduction of $D$. frondosus. On the contrary, D. primorjenisis (= D. dudkai syn. n.) has a broad distribution in the Sea of Japan.

The number of lobules present in the prostate of $D$. dudkai are described by Ekimova et al. (2016: 31) as being among the "most important diagnostic characters" for the genus Dendronotus. This is inaccurate, as Ekimova et al. (2016: 32) indicate 16-30 prostatic lobules for $D$. frondosus, whereas 12-14 lobules are described for $D$. dudkai 
(Ekimova et al. 2016: 37). However, the holotype of D. primorjensis possesses no less than 19 lobules in the prostate clearly implying that variability of numbers of prostatic lobules in the genus Dendronotus can be significant, and therefore cannot be speciesdiagnostic. The number of prostate lobules has recently been shown in Korshunova et al. (2016) to be an unreliable character in several Dendronotus species.

Unfortunately, the description of $D$. dudkai contains a number of problems that prevent the repetition of their results obtained by molecular phylogenetic analysis. Despite the presence of a molecular analysis that was based on "additional material" (i.e. non-type specimens) no molecular data is available for the type material. According to their Table 1 and "Type material" section (Ekimova et al. 2016:19-21, 33-35) five specimens were listed as type material for D. dudkai, but the molecular data for only one paratype (ZMMU Lc-40366) was registered at GenBank; however, this voucher number for this paratype of $D$. dudkai does not exist in GenBank: specimen W203 was registered at GenBank instead of specimen ZMMU Lc-40366, but specimen W203 is completely absent in the "Material" list or Table 1. In addition, no illustrations of the holotype of $D$. dudkai were provided nor were characters of the holotype mentioned in the description. Thus, the analysis of Ekimova et al. (2016) leads to the conclusion that there is no evidence that description of $D$. dudkai is based on the primary type, i.e. the holotype. According to the Recommendations 73A, 73B, and 73C of ICZN (1999) the "author who establishes a new nominal species-group taxon should designate its holotype in a way that will facilitate its subsequent recognition", "an author should designate as holotype a specimen actually studied by him or her, not a specimen known to the author only from descriptions or illustrations in the literature", and "an author who establishes a new nominal species-group taxon should publish at least the following data concerning the holotype, if they are relevant and known to the author, including: 73C.1. its size or the size of one or more relevant organs or parts." Thus, the absence of the holotype's morphological (and molecular data), and even its measurements in the original description of Ekimova et al. (2016) do not allow anyone to recognize it.

\section{Conclusions}

The morphological and molecular data provided in this publication and two previous studies (Martynov et al. $2015 \mathrm{a}$, b) conclusively demonstrate that $D$. primorjensis is a valid species as per current ICZN regulations (ICZN 1999). The integrative taxonomy (Dayrat 2005) presented here indicate that D. primorjensis and D. dudkai are one and the same species, and that $D$. primorjensis has taxonomic priority over $D$. dudkai published one year later. The species epithet $D$. dudkai is therefore to be considered a junior synonym of $D$. primorjensis. 


\section{Acknowledgements}

We are grateful to Vitaly Litvinenko and Andrey Maksimovsky (Dive Center Aquamax, Nakhodka city) for organizing the dives in Spokoinaya Bay, the Sea of Japan on 25 Sept 2014, and also to A.G. Bogdanov and G.N. Davidovich (Electron Microscopy Laboratory, Moscow State University) for support with electron microscopy. D.M. Schepetov is thanked for work with Genetic Analyser. Dendronotus dudkai was named in honour of Konstantin Dudka, a staff diver of the Institute of Marine Biology FEB RAS. We unreservedly apologize to Mr. Konstantin Dudka for any potential inconvenience or embarrassment. The study is supported by the Russian Science Foundation (grant 14-50-00029, SEM and molecular studies, depository of specimens), by Research project of MSU Zoological Museum (AAAA-A16-116021660077-3), and in 2013-2015 was supported by the Russian Foundation for Basic Research (grant 13-04-01641a), including an expedition grant during the course of which Dendronotus primorjensis type material had been collected.

\section{References}

Akaike H (1974) A new look at the statistical model identification. IEEEE Transactions on Automatic Control 19: 716-723. doi: 10.1109/TAC.1974.1100705

Dayrat B (2005) Toward integrative taxonomy. Biological Journal of the Linnean Society 85: 407-415. doi: 10.1111/j.1095-8312.2005.00503.x

Dayrat B, Tillier A, Lecointre G, Tillier S (2001) New clades of Euthyneuran Gastropods (Mollusca) from $28 \mathrm{~S}$ rRNA sequences. Molecular Phylogenetics and Evolution 19: 225-235. doi: 10.1006/mpev.2001.0926

Diving Center Aquamax (2014) Diving Center Aquamax. http://diving25.ru/news/177-kandidaty-biologicheskih-nauk-aleksandr-martynov-i-tatjana-korshunova.html [30.09.2014]

Edgar RC (2004) MUSCLE: multiple sequence alignment with high accuracy and high throughput. Nucleic Acids Research 32: 1792-1797. doi: 10.1093/nar/gkh340

Ekimova I, Korshunova T, Schepetov D, Neretina T, Sanamyan N, Martynov A (2015) Integrative systematics of northern and Arctic nudibranchs of the genus Dendronotus (Mollusca, Gastropoda), with descriptions of three new species. Zoological Journal of the Linnean Society 173: 841-886. doi: 10.1111/zoj.12214

Ekimova IA, Schepetov DM, Chichvarkhina OV, Chichvarkhin AY (2016) Nudibranch molluscs of the genus Dendronotus Alder et Hancock, 1845 (Heterobranchia: Dendronotina) from Northwestern Sea of Japan with description of a new species. Invertebrate Zoology 13: 15-42. doi: 10.15298/invertzool.13.1.02

Folmer O, Black M, Hoeh W, Lutz R, Vrijenhoek R (1994) DNA primers for amplification of mitochondrial cytochrome c oxidase subunit I from diverse metazoan invertebrates. Molecular Marine Biology and Biotechnology 3: 294-299. http://www.mbari.org/wpcontent/uploads/2016/01/Folmer_94MMBB.pdf

ICZN (1999) International Code of Zoological Nomenclature. The International Trust for Zoological Nomenclature, London, 306 pp. 
Korshunova T, Sanamyan N, Zimina O, Fletcher K, Martynov A (2016) Two new species and a remarkable record of the genus Dendronotus from the North Pacific and Arctic oceans (Nudibranchia). ZooKeys 630: 19-42. doi: 10.3897/zookeys.630.10397

Kumar S, Stecher G, Tamura K (2016) MEGA7: Molecular evolutionary genetics analysis version 7.0 for bigger datasets. Molecular Biology and Evolution 33: 1870-1874. doi: $10.1093 / \mathrm{molbev} / \mathrm{msw} 054$

Le HLV, Lecointre G, Perasso R (1993) A 28S rRNA based phylogeny of the Gnathostomes: first steps in the analysis of conflict and congruence with morphologically based cladograms. Molecular Phylogenetics and Evolution 2: 31-51. doi: 10.1006/mpev.1993.1005

MacFarland FM (1966) Studies on opisthobranchiate mollusks of the Pacific Coast of North America. Memoirs of the California Academy of Science 6: 1-546. http://biodiversitylibrary.org/page/3152823

Martynov AV, Sanamyan NP, Korshunova TA (2015a) New data on the opisthobranch molluscs (Gastropoda: Opisthobranchia) of waters of Commander Islands and Far-Eastern seas of Russia. Conservation of biodiversity of Kamchatka and coastal waters - Proceedings of XV international scientific conference Petropavlovsk-Kamchatsky. Kamchat Press, Petropavlovsk-Kamchatsky, 55-69. http://sanamyan.com/publications/martynov_sanamyan_korshunova_2015.pdf

Martynov AV, Sanamyan NP, Korshunova TA (2015b) Review of the opisthobranch mollusc fauna of Russian Far Eastern seas: Pleurobranchomorpha, Doridida and Nudibranchia. Bulletin of Kamchatka State Technical University 34: 62-87. doi: 10.17217/2079-03332015-34-62-87

Nylander JA, Ronquist F, Huelsenbeck JP, Nieves-Aldrey JL (2004) Bayesian phylogenetic analysis of combined data. Systematic Biology 53: 47-67. doi: 10.1080/10635150490264699

Palumbi SR, Martin AP, Romano S, McMillan WO, Stice L, Grabowski G (2002) The simple fool's guide to PCR. Department of Zoology Special Publication, University of Hawaii, Honolulu, 45 pp. http://palumbi.stanford.edu/SimpleFoolsMaster.pdf

Puillandre N, Lambert A, Brouillet S, Achaz G (2012) ABGD, Automatic Barcode Gap Discovery for primary species delimitation. Molecular Ecology 21: 1864-1877. doi: 10.1111/j.1365-294X.2011.05239.x

Puslednik L, Serb JM (2008) Molecular phylogenetics of the Pectinidae (Mollusca: Bivalvia) and effect of increased taxon sampling and outgroup selection on tree topology. Molecular Phylogenetics and Evolution 48: 1178-1188. doi: 10.1016/j.ympev.2008.05.006

Robilliard GA (1970) The systematics and some aspects of the ecology of the genus Dendronotus. Veliger 12: 433-479. http://biodiversitylibrary.org/page/42516695

Stout CC, Pola M, Valdés Á (2010) Phylogenetic analysis of Dendronotus nudibranchs with emphasis on northeastern Pacific species. Journal of Molluscan Studies 76: 367-375. doi: $10.1093 /$ mollus/eyq022

Stout CC, Wilson NG, Valdés Á (2011) A new species of deep-sea Dendronotus Alder \& Hancock (Mollusca: Nudibranchia) from California, with an expanded phylogeny of the genus. Invertebrate Systematics 25: 60-69. doi: 10.1071/S10027.144

Zwickl D (2006) Genetic algorithm approaches for the phylogenetic analysis of large biological sequence datasets under the maximum likelihood criterion. PhD Thesis, The University of Texas at Austin, Austin, 115 pp. https://repositories.lib.utexas.edu/handle/2152/2666 